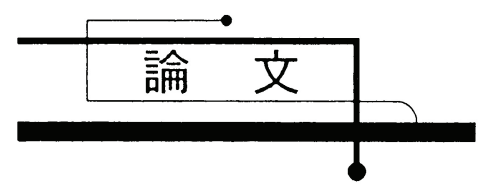

\title{
マイクロバブルによる浮上分離に関する研究*
}

\section{Study on Separation of Fine Particles Using Rising Microbubbles}

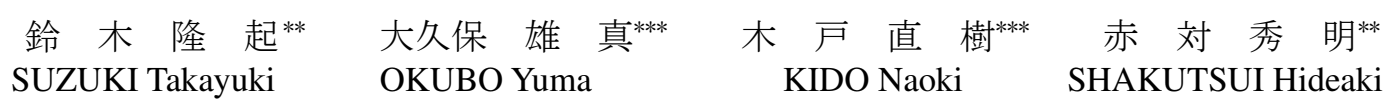

西 内 悠 祐 $^{\dagger}$

NISHIUCHI Yusuke
秦隆 志 ${ }^{\dagger}$

HATA Takashi
西山康 正 ${ }^{\dagger \dagger}$

NISHIYAMA Yasumasa

$\begin{array}{lll}\text { 清 水 孝 悦㹨 } & \text { 佐 野 } \text { 正 }^{\dagger \dagger} \\ \text { SHIMIZU Takayoshi } & \text { SANO Tadashi }\end{array}$

\begin{abstract}
Bubbles with a diameter of 1 to $100 \mu \mathrm{m}$ are defined as microbubbles (hereinafter, this is called "MB"), and are used for floatation separation because of their adhesion to suspended substances. However, there are few research reports on floatation separation, and standardization for device design has not been performed, so improving the efficiency of floatation separation devices has become an issue. Therefore, in this study, the experiments were carried out to clarify the floatation separation characteristics by microbubbles as a basic research of floatation separation by microbubbles. In the experiment, the soft flour was used as a suspended substance, and as basic characteristics, the state of adhesion with microbubbles, the relationship with bubble diameter, and the rising velocity rate were measured. In addition, as the actual floating separation performance, the concentration time with each initial concentration was investigated. The conclusions are as follows: About $60 \%$ of the adhered form of the microbubbles and the soft flour was observed as a form in which a single microbubble adhered to the soft flour. The number of microbubbles with a bubble diameter of $80-90 \mu \mathrm{m}$ was attached in the case of single microbubble attachment to flour is large. In the floating separation characteristics, floatation the soft flour concentration in the tank decreases sharply at the short time, and then gradually decreases. The higher the initial concentration, the longer the processing time required to reach the target concentration, but the tendency of the concentration decrease was the same. The final concentration remains around $20 \mathrm{ppm}$ in all experimental conditions. These results are important for standardization of floatation separation characteristics in the future.
\end{abstract}

Keywords: Microbubble, Flotation separation, Visualization, Bubble diameter, Rising velocity

\section{1. 緒 言}

自然界に存在する気泡の中で、直径 $100 \mu \mathrm{m}$ 末 満の気泡をファインバブル、直径が 1 100 $\mu \mathrm{m}$ の
気泡をマイクロバブル (以下 MB とする)、1 $1 \mu \mathrm{m}$ 未満の気泡をウルトラファインバブルと、国際標 準化機構（ISO）において定義されている[1]。こ

\footnotetext{
* Received: 17 July 2020 / Accepted: 30 October 2020 / Published online: 21 December 2020

***神戸市立工業高等専門学校機械工学科 干651-2194 兵庫県神戸市西区学園東町 8-3

TEL: (078)795-3311 FAX: (078)795-3314 E-mail: taka8170@kobe-kosen.ac.jp

*** 神戸市立工業高等専門学校専攻科機械システム工学専攻

†高知工業高等専門学校ソーシャルデザイン工学科

†株式会社西山ポンプサービス

枯ひようご TTO 合同会社
} 
れらファインバブルには、洗浄効果、成長促進作 用、水質改善効果、溶存酸素量の増加などの特性 があることから、農業、水産業、食品業、工業、 医療など様々な産業分野にて応用されている[2]。

これら応用技術のひとつに MB による浮上分 離技術があり、食品業や環境分野における排水や 污水処理において、液中に拡散している不溶性物 質のみを浮上させて分離する技術である。MB は 負に帯電している、単位体積あたりの表面積が大 きい、浮上速度が非常に遅いなどの特徴がある[2] ことから、効率的に懸濁液中の固形物に付着し、 いわゆる浮輪効果で、浮上分離を可能とする。そ のため、MB による浮上分離効果に着目して、寺 坂らは、酸化鉄微粒子を固形物とし、 $\mathrm{pH}$ および 界面活性剤を調整することにより、浮上分離が促 進されることを報告[3]している。また、Wang ら は、浮上分離塔を旋回流部と上昇流部で構成する ことにより、付着率の向上に加えて、脱離率の低 減を図っている[4]。また、鮎川らや Etchepare ら は油水分離に MB を利用した浮上分離を行い[5, 6]、田村はトリチウムを含む污染水に MBによる 浮上分離を用いることでトリチウム濃度の低減 に成功している[7]。一方で、MB を用いた排水処 理システムは、一般的な排水処理システムとして は広く実用化には至っていない。この原因として、 MB の発生量は、下水処理などで利用される加圧

(減圧) 浮上分離法と比べ比較的少ないことから、 大規模処理に適しているとは言えず利益性にそ しいことや、無数に存在する処理対象に対する $\mathrm{MB}$ による浮上分離効果が整理され、標準化され ていないため、容易に適用できないことが大きな 原因となる。実際に、MB による浮上分離に関す る研究例は、前述した程度であり、また企業によ る独自開発はブラックボックス化が多く、標準化 や装置の最適化に必要な基礎的研究が不足して いることが大きな問題である。しかし、MBによ る浮上分離技術は、大規模処理施設ではなく、例 えば、水質污濁防止法で規制されていない $50 \mathrm{~m}^{3}$ / 日以下の排水を行う小規模排水施設群に対して 規模に見合った小型で高効率な処理システムの 確立としての可能性が考えられる。実際、小規模 排水施設群に特化した排水処理システムは多く 存在せず、局所的な環境污染も問題となっている。

そこで本研究では、MB を用いた浮上分離技術 確立のための基礎的研究の位置づけとして、MB
による浮上分離に対する標準化 (どのような排水 対象にどのような MB が適しているか)に向けて、 食品業等で多く問題となる有機物（薄力粉）を対 象に、MB による付着状況を観察するとともに、 MB の代表的な特性である気泡径に着目し、気泡 径と有機物の付着率に対する影響を検討する。ま た、水質污濁防止法の基準值である $150 \mathrm{ppm}$ をひ とつの基準とし、MB による浮上分離特性を評価 することを目的とする。

\section{2. 実験装置および方法}

\section{$2.1 \mathrm{MB}$ 発生装置}

$\mathrm{MB}$ 発生装置には、(株西山ポンプサービス社製 （NPS-MBG-S26）を使用した。本装置では、MB の一般的な発生方式である旋回方式と加圧溶解 方式の複合方式となっており、ポンプから吸い込 まれた液体は加圧されることで十分な空気が溶 解され、流出側先端の旋回部で減圧・せん断され ることで、大量の MB を発生させることが可能と なる。本装置においては、吐出流量は $5.5 \mathrm{~L} / \mathrm{min}$ 、 吸込空気量は $500 \mathrm{~mL} / \mathrm{min}$ 程度、出口付近での平 均気泡径は $48 \mu \mathrm{m}$ 、数密度は 6000 個 $/ \mathrm{mL}$ 程度で ある。なお、本研究で使用した作動流体は水道水 であり、水温は $20 \pm 1{ }^{\circ} \mathrm{C}$ 範囲としている。

\section{2 観察実験}

Fig. 1 に実験装置の概略を示す。実験装置は、 試験部水槽、ポンプおよび MB 発生器からなる閉 ループ系である。

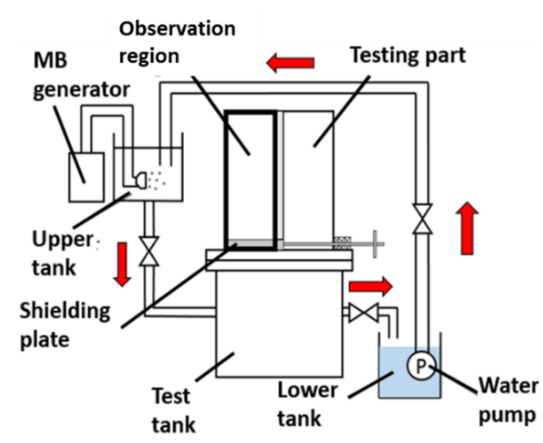

Fig. 1 Experimental appratus for observation.

試験部水槽の上部は、断面 $210 \mathrm{~mm} \times 20 \mathrm{~mm}$ の 透明アクリル樹脂製であり、2 領域に分割されて いる。一方の断面 $100 \mathrm{~mm} \times 20 \mathrm{~mm}$ 、高さ $600 \mathrm{~mm}$ が観察領域であり、試験部下端には、横方向にス ライド可能な遮蔽版が設置されている。実験時に 
は、まず遮蔽板を観察領域下端に移動させて、観 察領域と下部水槽を遮断しておく。次に、観察領 域内に薄力粉と水道水を混ぜておいた懸濁液を 入れておき、下部水槽には MB を充満させておく。 ここから遮蔽板をゆっくり移動させて、観察領域 内の乱れを減らしつつ、浮上分離過程を観察する。

Fig. 2 に発生器出口付近と観察領域内での気泡 径分布を示す。なお気泡径分布は、画像解析式粒 子径分布測定装置 PartAn SI（マイクロトラック・ ベル(株) により測定した。本結果より発生気泡の ピークは、発生器出口付近よりも観察領域での気 泡径分布が右側にシフトしており、平均気泡径に おいても約 $50 \mu \mathrm{m}$ から、約 $63 \mu \mathrm{m}$ と発生器出口付 近よりも平均して気泡径が大きくなっているこ とが確認できる。発生器出口付近と観察領域内で 気泡径に違いがあるのは、発生器出口から観察領 域内に到達するまでに、浮力の影響により、径が 大きい気泡が観察領域内に入りやすいことや、溶 存気体の析出、気泡同士の合体の影響によるもの だと考えられるものの、明確にはなっていない。

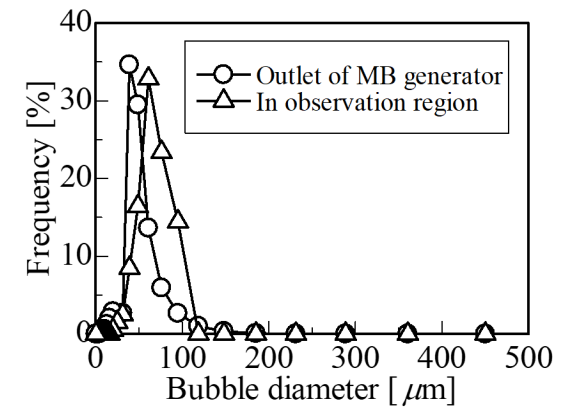

Fig. 2 Bubble diameter distribution in observation region.

浮上の様子は、300 倍の拡大レンズ（松電舎、 RTK-6F-110）を取り付けた高速度ビデオカメラ

(Photron、FASTCAMMC2.1) により撮影した。 䀣濁粒子には、薄力粉（平均粒子径約 $60 \mu \mathrm{m}$ ）を 用い、実験直前に、試験容器に水道水と薄力粉を 投入し、十分攪找寸ることで作成している。また、 採取した懸濁液に対して、流動電位測定装置 Stabino（マイクロトラック・ベル(株) により、薄 力粉のゼータ電位の測定も行った。なお、本一連 の実験においては、䀣濁液作成後直ぐに実験を行 うため、䀣濁液の時間による性質的変化はないも のとしている。

本実験では、観察に加えて気泡径および粒子径 の測定 (本画像処理においては、15 $\mu \mathrm{m}$ 以下の撮
影物については、誤差の都合上、除外している) も行い、気泡径や粒子径は画像処理によって面積 を測定し、その面積と等価な面積を持つ円の直径 に換算した。画像処理においては、まず目視観察 により、鮮明な画像に対して、輪郭抽出のための 閾值を決定し、抽出された画像のみに対して、等 価直径に変換している。なお、薄力粉においては、 球状ではないため、本撮影方法では奥行方向が不 明となるものの、まずは、簡易的な計測方法によ り、薄力粉に付着しやすい MB の気泡径の傾向を 調べた。

\section{3 浮上分離による水質改善実験}

本研究では、付着状態の観察に加えて、緒言で 示したように浮上分離特性についても検討する。

Fig. 3 に実験装置の概略を示す。

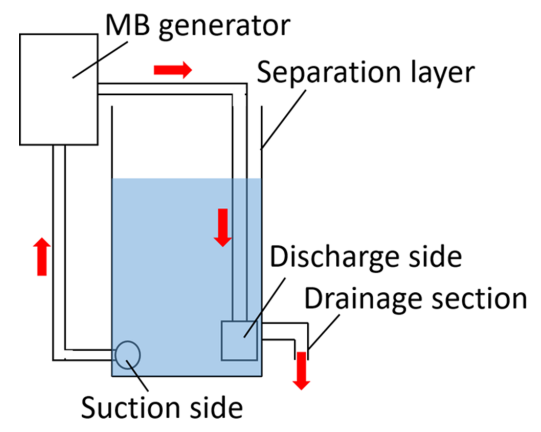

Fig. 3 Experimental apparatus for investigation of floatation separation chracteristics.

分離槽は断面 $300 \mathrm{~mm} \times 300 \mathrm{~mm}$ 、高さ $900 \mathrm{~mm}$ の透明アクリル樹脂製であり、底面より $200 \mathrm{~mm}$ の位置に排水弁を取り付けている。MB の発生部 および吸込み部は分離槽下部に固定されており、 懸濁液は分離槽内部で循環する閉ループ系とな っており、MB 発生装置は観察実験にて用いたも のと同じである。なお、内部で発生する MB の気 泡径分布は、観察位置で多少異なるものの、Fig. 2 の発生出口直後の分布とほぼ同様となることを 確認している。本実験では初期濃度および処理時 間を変更し、浮上分離による水質改善効果を検討 する。処理時間は MB 発生器を閉ループ系にて運 転させている時間である。分離槽液量は $54 \mathrm{~L}$ に 固定し、懸濁液は水道水に薄力粉を分散させるこ とで、300、600、900 ppmに調整した。また MB による処理時間 (MB 発生器運転時間) は 5、10、 $30 、 60$ 分とし、MB 発生器運転停止後、濃度がほ 
ぼ一定となる時間まで観察した。実験では、連続 処理及び経過観察の過程で 5 分おきに排水部より 溶液を採取し、その成分を濁度計（ProDSS マルチ 水質センサー、ワイエスアイ・ナノテック株）に より測定する。その後、濁度を事前に検定した濃 度との検定曲線から濃度に換算し、水質改善効果 を評価した。なお、試行回数は各条件に対して3 回とし、再現性は最大誤差 $10 \%$ 以内であること を確認している。本実験では全水量に対する排水 量が少量であるため、実験における水位变化の影 響を考慮しない。

\section{3. 実験結果および考察}

\section{1 観察実験}

\subsection{1 付着状況}

Fig. 4 に撮影した浮上分離状況の一例を示す。 $\mathrm{MB}$ による薄力粉の浮上分離は、薄力粉に対して、 MB が 1 つもしくは、複数個付着して浮上する様 子が観察できた。Fig. 4(a)は 1 つの MB が薄力粉 に付着して浮上させている様子 (以下、単体付着 と呼ぶ) である。この画像のように MB は薄力粉 を持ち上げるのではなく、薄力粉を吊り上げるよ うにして浮上させていることが観察できた。Fig. 4(b)、(c)、(d)では 2 つ以上の MB が薄力粉に付着 して浮上させている様子 (以下、複数付着と呼ぶ) である。複数付着には、単体付着と同様に薄力粉 を吊り上げて浮上させるものや、小さい気泡が薄 力粉に複雑に付着しているものなど付着状態は 様々であった。

Fig. 5 に本実験で使用する懸濁液中の薄力粉の ゼータ電位を示す。薄力粉の等電点は約 $\mathrm{pH}=5.7$ であり、本実験では、溶媒に水道水を用いている ため、 $\mathrm{pH}$ は概ね 6 8 程度である。すなわち本実 験における薄力粉のゼータ電位は負であること が考えられる。浮上分離の付着のメカニズムとし ては、マイクロバブルが負、懸濁物質が正に帯電 することによる電気的な吸着か、疎水性相互作用 によるもの[2]が挙げられるが、䀣濁物資が負に帯 電していることから、本実験においては後者によ る影響が大きいと考えられる。

Table 1 に、どの付着状態が多く存在している かを確認するため、観察した 500 個の MB に対 して、付着なし、単体付着、 2 個付着、複数付着 （気泡数が 3 個以上）に分類した個数の結果を示 す。なお、実験条件は、2 章で示した単一条件で

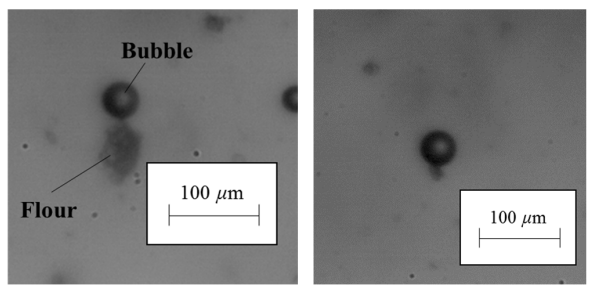

(a) Single attachment of MB to soft flour

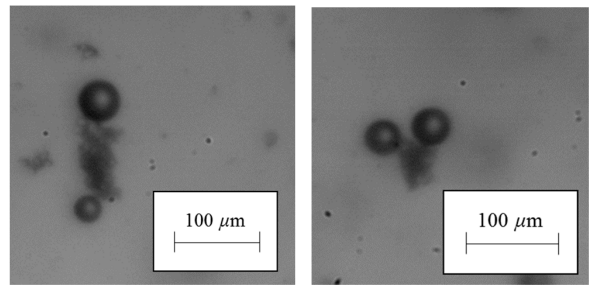

(b) Double attachements of MB to soft flour

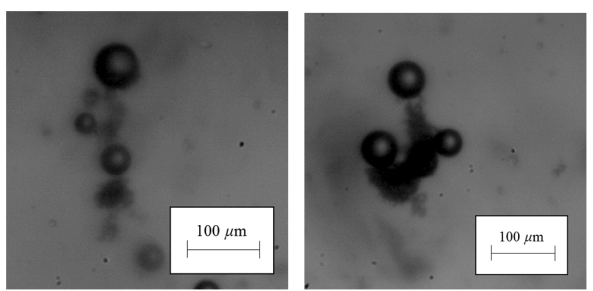

(c) Tripple attachements of MB to soft flour
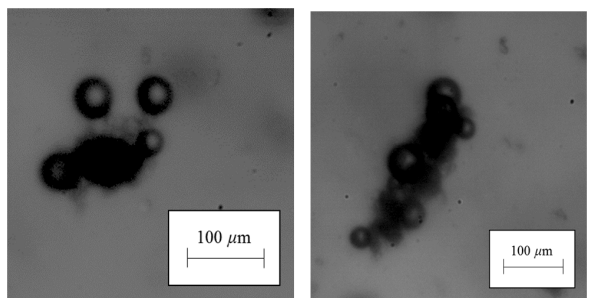

(d) Many attachements of MB to soft flour

Fig. 4 Adhesion state of MB and soft flour.

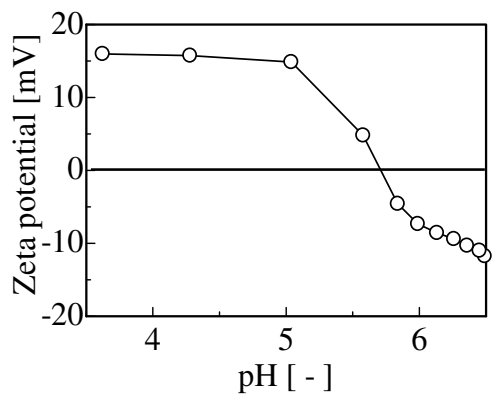

Fig. 5 Zeta potential of soft flour in suspension water.

あり、できる限り観察位置での影響を少なくする ため、撮影位置は、観察領域を上、中、下の 3 か 所に分け、その中央付近で撮影したものを合算し 
ている。それぞれ撮影している。全状態でみると、 付着せずに浮上している気泡が最も多く、全体の 約 59 \%であった。次いで多かったのは単体付着

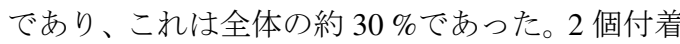
および複数付着は合わせて約 $11 \%$ \%市った。こ の結果より、単体付着の個数は複数付着の 3 倍程 度の個数であり、単体付着が浮上分離特性におい て大きく寄与していることが考えられる。そのた め、本実験では、以降気泡径計測などは単体付着 に対してのみ行うこととした。

Table 1 Ratio of state of adhesion.

\begin{tabular}{|c|c|c|}
\hline State of adhesion & Number & Ratio [\%] \\
\hline Not attached & 294 & 59 \\
\hline Single attached & 150 & 30 \\
\hline Double attached & 32 & 6 \\
\hline Multiple attached & 24 & 5 \\
\hline
\end{tabular}

\section{1 .2 気泡径分布および直径比分布}

Fig. 6 に薄力粉を含んだ䀣濁液中を、単一で浮 上している気泡と単体付着している気泡の気泡 径分布を示す。気泡径のピークはそれぞれ付着な しで 60 70 $\mu \mathrm{m}$ 、付着ありで 80 90 $\mu \mathrm{m}$ にあること がわかる。よって薄力粉の浮上分離に対しては気 泡径 80 90 $\mu \mathrm{m}$ の MB が有効であることが考えら れる。次に、薄力粉の粒子径との比較を行うため、 直径比を用いて考察を行った。Fig. 7 に直径比の 度数分布を示す。直径比は薄力粉の粒子径を $\mathrm{MB}$ の気泡径で除したパラメータである。直径比のピ 一クは 0.4 0.5にあり、全体の約 $64 \%$ 直径比 1 以下に集中していた。すなわち薄力粉よりも径が 大きい MB が付着しているものが多いといえる。

\subsection{3 浮上速度の比較}

Fig. 8 に薄力粉を含んだ懸濁液にて、単一で浮 上している気泡の浮上速度を、Fig. 9 に単体付着 にて浮上している気泡の浮上速度を示す。なお、 浮上速度は観察動画から単位時間当たりの移動 距離で算出している。曲線は単一で浮上している 気泡の浮上速度をよく示す Stokes の式である。い ずれも気泡径が大きくなると浮上速度も単調増 加するという定性的な傾向は一致していること がわかる。一方で、Fig. 8 では浮上速度が平均的 に Stokes の式で表される浮上速度よりも高くな っていることがわかる。これは本実験装置におい ては、遮蔽板を外すことで、観察領域下部で発生 させた MB を観察領域内（静止流体中）に流入

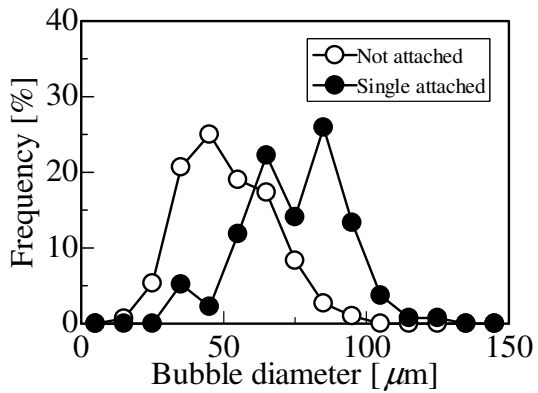

Fig. 6 Bubble diameter distribution of MB not attached and single MB attached to soft flour.

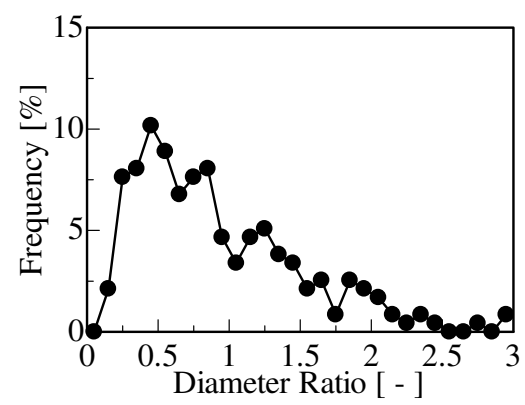

Fig. 7 Diameter ratio distribution of MB not attachedand single $\mathrm{MB}$ attached to soft flour.

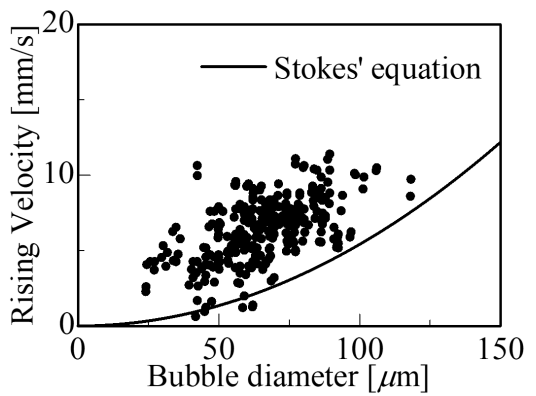

Fig. 8 Rising velocity of not attached bubbles.

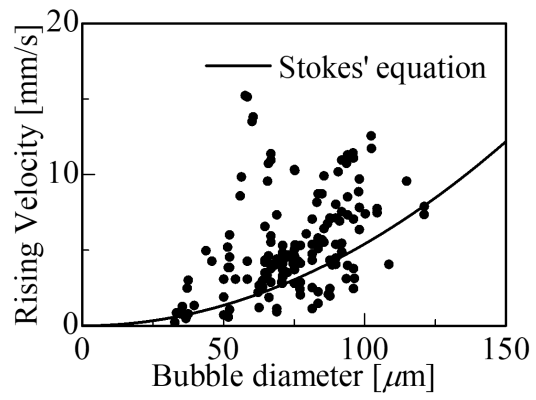

Fig. 9 Rising velocity of single attached bubbles.

させる構造となっているため、MB が静止流体中 を多数浮上することで誘起される上昇流の効果 
によって、単一気泡としての浮上速度よりも高く なったためであると考えられる。また、上昇速度 のばらつきは、上昇流が局所的には異なることや、 気泡間における電気的な反発による上昇速度へ の影響によるものであると考えられる。なお、観 察領域内の平均的な上昇速度は時間依存により 低くなるが、今回は時間依存による変化は考慮し ておらず、上昇流の計測は、遮蔽板を外した直後 の測定を繰り返して行っている。一方 Fig. 9 では 単一で浮上しているときと比較して、全体的なば らつきが大きく、また、浮上速度が平均的に低く なっていることがわかる。これは、単純に薄力粉 が付着したことにより重量が大きくなり浮上速 度が低下寸ることに加えて、薄力粉が付着したこ とによる、局所的な上昇流の低下や、沈降による 下降流の存在などにより、複雑な内部流れの影響 を受けるためであると考えられる。

\section{2 水質改善実験}

\section{2 .1 処理時間による影響}

Fig. 10 に浮上分離特性として、各初期濃度に対 する濃度の時間変化を各処理時間に対して示す。 また、Fig. 11 に Fig. 10 から初期濃度で無次元化 した濃度比の時間変化を示す。なお、図中の破線 は、処理時間（処理時間到達後以降は MB の発生 を停止)を示している。

処理時間によらず、本実験装置における浮上分 離特性は、同様の傾向を示しており、MB 発生後、 急激に濃度は減少し、その後、ある一定の濃度比 に近づくことが確認できる。このとき、水槽上部 に濃縮層が観察されている。これは、浮上分離開 始直後では、単位体積あたりの懸濁物質数が多く なり、MB と接触する可能性が高まることで、付 着・浮上が活発になり、急激に濃度が低減すると 考えられる。しかし、浮上分離がある程度進むと、

MB が付着していない懸濁物質が減少することに より、䋰濁物質との遭遇確率が減少するためであ ると考えられる。

処理時間に対しては、処理時間が短い場合、定 量的な濃度減少率は初期濃度に依存し、300 ppm の場合が比較的早く濃度比は減少していく。また、 処理時間が長くなると、最終的な濃度はより小さ くなることが確認できる。しかし、濃度比が約 $20 \%$ 程度となると、減少率は、初期濃度によらず、ほ ぼ同程度になることが確認できる。これは、本実 験で使用した䀣濁物質の総量の約 $20 \%$ 程度は MB

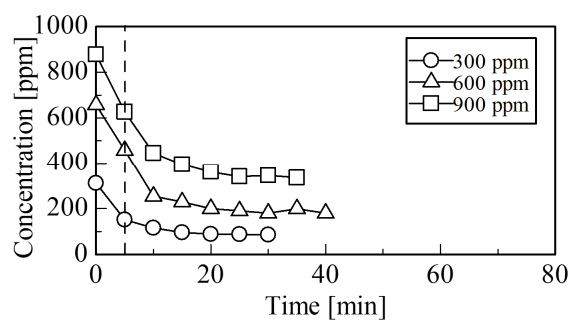

(a) 5 minutes of processing time

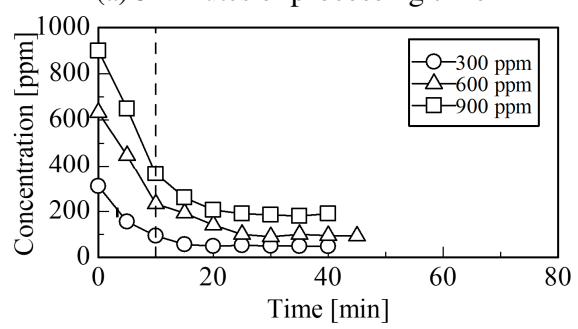

(b) 10 minutes of processing time

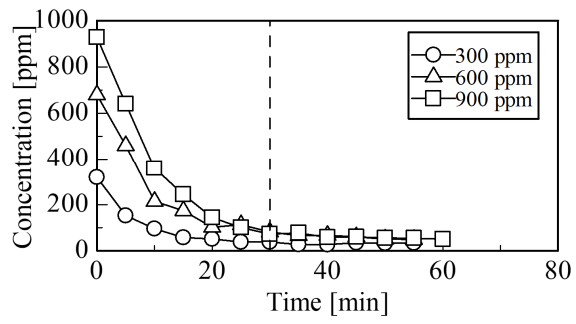

(c) 30 minutes of processing time

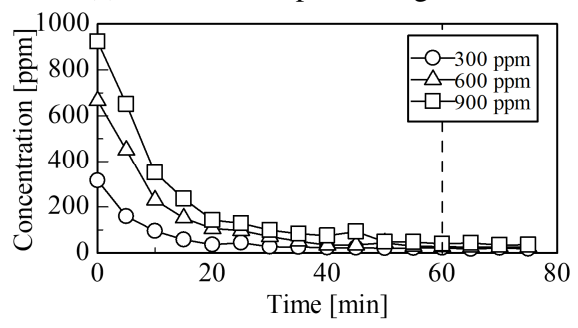

(d) 60 minutes of processing time

Fig. 10 Concentration for processing time.

に付着しにくい状態になっているためであると考 えられるものの、詳細は不明であり、今後検討し く予定である。処理時間 5 分では、300、600 ppm では約 $30 \% 、 900 \mathrm{ppm}$ では約 $40 \%$ までの低下に留 まっている一方、処理時間 10 分では約 $20 \%$ まで 減少、処理時間 30 分では約 $10 \%$ まで減少、処理 時間 60 分では、初期濃度の約 $5 \%$ 程度まで、濃度 を低下させることが確認できる。これは、処理時 間に応じて分離槽内の気泡数が多くなり、かつ維 持されるため、より多くの眯濁物質を浮上させる ことができるためだと考えられる。なお、本実験 


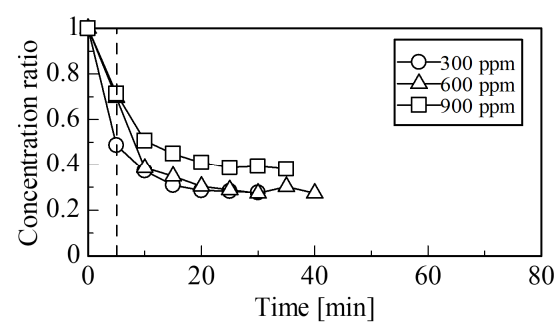

(a) 5 minutes of processing time

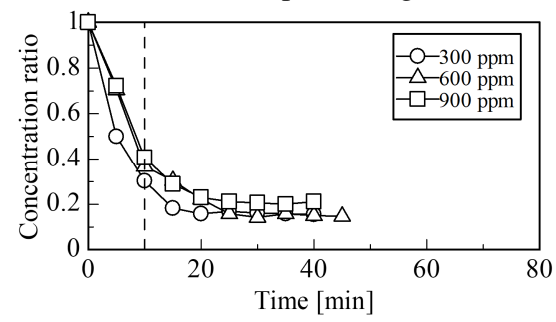

(b) 10 minutes of processing time

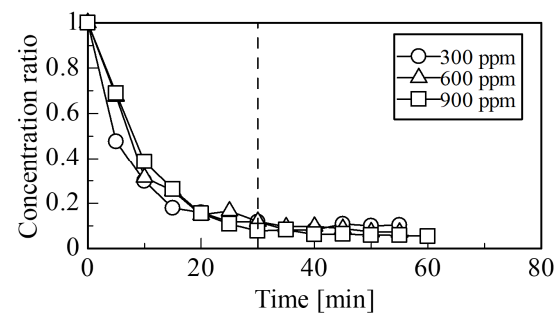

(c) 30 minutes of processing time

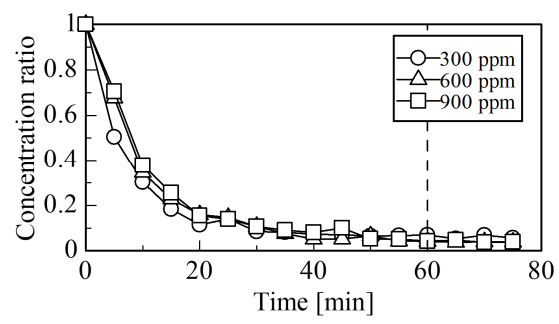

(d) 60 minutes of processing time

Fig. 11 Concentration ratio by initial concentration for processing time.

においては、最終的な濃度は初期濃度によらず、 $20 \mathrm{ppm}$ 前後で最低值を迎え、それ以上は減少させ ることができなかった。これは濃度低下による MB と粒子の遭遇率の低下が影響していることに 加え、MB ではある大きさ以下の粒子の付着が困 難となるためであると考えられる。この点は、今 後、残存している粒子径分布を計測し、明確にす る予定である。なお, Fig. 6 で示した結果におい て、付着している最小の薄力粉の等価直径は約 $20 \mu \mathrm{m}$ 程度であり、それ以下の薄力粉が残存して
いるものと思われる。目的とする濃度に対しては、 最終的に MB で処理しきれない懸濁物質を、MB 処理後に、凝集剂を用いて回収する必要があるも のの、凝集剤の利用は最小限に留めることが可能 であると考えられる。

\subsection{2 初期濃度に対する目的濃度達成時間}

Fig. 12 に各処理時間における、各初期濃度に対 する、50、100、150 ppm に到達するまでの必要時 間を示す。なお、処理時間 10 分の場合、目的濃度 に達していない条件があるため、一部の表記とな っている。

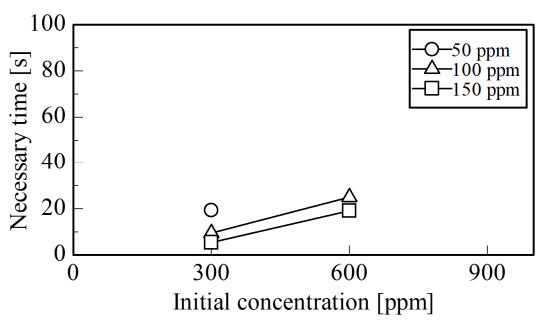

(a) 10 minutes of processing time

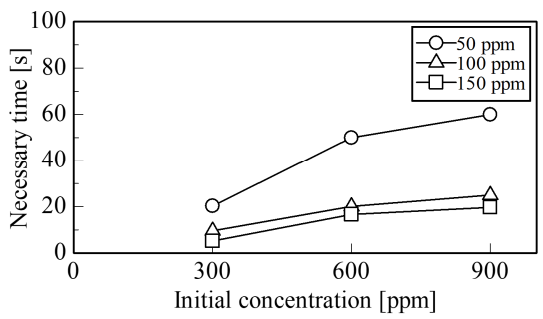

(b) 30 minutes of processing time

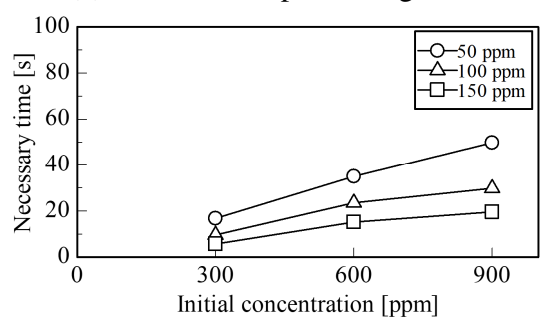

(c) 60 minutes of processing time

Fig. 12 Processing time required for 50, 100, $150 \mathrm{ppm}$.

処理時閒 $60 \mathrm{~min}$ の場合、各目的濃度における初 期濃度に対する必要時間は単調増加となることが 確認できる。しかし、処理時間 $30 \mathrm{ppm}$ では、初期 濃度が 300 ppm から 600 ppm、600 ppm から 900 ppm の場合には、その傾きが異なっている。これ は、処理時間 $60 \mathrm{~min}$ の場合、MB 発生中にほぼ目 的濃度に達している一方、処理時間 $30 \mathrm{~min}$ の場合、 目的濃度達成前に MB の発生が止まることから、 
MB 発生中および静止後では、浮上分離性能が低 下寸ることためであると考えられる。なお、処理 時間 $10 \mathrm{~min}$ についても、初期濃度に対する必要時 間は単調増加であることが推定される。一方、目 的濃度に対しては、同一初期濃度に対して、150 ppm から 100 ppm までに達する時間と、100 ppm から 50 ppm に達する時間は、一定時間ではなく、 $100 \mathrm{ppm}$ から 50 ppm に達する時間が長くなってい る。これは、3.2.1で示したように、内部の濃度が 減少することにより、MB の付着確率が減少する ためであると考えられる。

これらより目的濃度に対して、初期濃度に応じ た処理時間が存在すると言え、最適化を行うこと で、過剰な処理時間による消費電力の無駄を削減 できることが考えられる。本実験装置においては、 目的濃度を水質污濁防止法の基準值である 150 ppm とした場合、処理時間 $10 \mathrm{~min}$ でも初期濃度 600 ppm では 20 分程度で達成可能であり、また、処理 時間を $30 \mathrm{~min}$ にすると、900 ppm の高濃度でも約 20 分で処理可能である。そのため、本実験範囲に おいては、MB の浮上分離効果により、水質污濁 防止法の基準值に対して十分な処理能力があるこ とが確認できた。一方、MB による浮上分離性能 は、MB の発生条件、初期濃度、実機スケールな ぞ、様々な条件が関与している。そのため、本論 文の結果がただちに、全ての浮上分離性能に対し て成立する訳ではなく、それらを考慮した無次元 パラメータでの浮上分離性能の整理が必要不可欠 である。なお、本実験でも無次元パラメータによ る整理を試みたものの、実験条件が不足しており、 完全な定式化には至っていない。しかし今後、様々 な条件に対して浮上分離性能を収集し、無次元パ ラメータにより定式化することで、装置設計や最 適化に有用な情報となると考えられる。

\section{4. 結 言}

本研究では気泡および粒子の直径、浮上分離時 における処理時間、初期濃度が浮上分離特性に及 ぼす影響を明らかにすることを目的に実験を行 い、以下のことを明らかにした。

(1) マイクロバブルと薄力粉の付着形態は、約 $60 \%$ 単一のマイクロバブルが薄力粉に付 着、約 $10 \%$ 複数のマイクロバブルが薄力 粉に付着する形態として観察された。

（2）本実験において薄力粉を含む䀣濁液中では、
気泡径 80 90 $\mu \mathrm{m}$ のマイクロバブルがもっと も多く付着しており、約 $64 \%$ の気泡が自身 よりも小さい粒子を浮上させていた。このこ とから薄力粉の浮上分離に対しては気泡径 80 90 $\mu \mathrm{m}$ の気泡が有効であると推測される。

(3) 浮上分離特性において、処理時間が 10 分程 度までは濃度は急激に低減し、その後は漸減 していく。

（4）初期濃度が高くなることで、目標濃度に達す るまでに必要な処理時間は長くなるものの、 濃度減少の傾向は同様であった。また最終的 な濃度は $20 \mathrm{ppm}$ 前後でとどまる。

(5) 目標濃度となるまでに必要な処理時間は、処 理時間が十分であれば、初期濃度が増えれば 単調に増加する。

\section{参考文献}

[1] International Organization for Standardization, Fine Bubble Technology - Characterization of Microbubbles - Part 1: Off-Line Evaluation of Size Index, 21910-1 (2020).

[2]Terasaka, K., Himuro, S., Andou, K. and Hata, T., Introduction to Finebubble (in Japanese), The Nikkan Kogyo Shimbun, Ltd., Tokyo (2016).

[3] Terasaka, K., Aoki, S. and Kobayashi, D., Removal of Iron Oxide Fine Particles from Water Using Microbubble Flotation, Progress in Multiphase Flow Research, Vol. 3, 43-50 (2008).

[4] Cao, Y., Liu, Y., Shi, R., Wang, A., Wang, L., Xu, Y. and Yan, X., Bubble Behaviors in a Lab-Scale Cyclonic-Static Micro-Bubble Flotation Column, Asia-Pacific Journal of Chemical Engineering, Vol. 11(6), 939-948 (2016).

[5] Ayukawa, D., Imai, T., Le, V. T., Kanno Y., Higuchi, T., Yamamoto, K. and Sekine, M., Performance of Combined Micro- and Normal Bubbles in Separation of Fine Oil-in-Water Emulsions from Palm Oil Mill Effluent, Journal of Japan Society on Water Environment, Vol. 38 (5), 159-166 (2015).

[6] Azevedo, A., Etchepare, R., Oliveira, H. and Rubio, J., Separation of Emulsified Crude Oil in Saline Water by Dissolved Air Flotation with Micro and Nanobubbles, Journal of Separation and Purification Technology, Vol. 186, 326-332 (2017).

[7] Tamura, I., SepaTech Microbubble System Successfully Decrease Tritium Concentration in Water, Studies in Science and Technology, Vol. 5(2), 137-138 (2016). 